\title{
Toxicity effect of Cobalt on total protein and carbohydrate of cyanobacteria Spirulina platensis
}

\author{
Hamida. EL. Elsalhin ${ }^{1} \&$ Hanan. M. Abobaker ${ }^{1}$ and Marfoua. S. Ali ${ }^{2}$ \\ ${ }^{l}$ Botany Department, Faculty of Science, Omar El-Mokhtar University, El-Beyda-Libya \\ ${ }^{2}$ Zoology Department, Faculty of Science, Omar El-Mokhtar University, El-Beyda-Libya
}

\begin{abstract}
The nano-planktons are considered to be the most important marine phytoplankton components since they constitute the basic food of almost all the marine larval organisms and other marine creatures. They are considered to be the first organisms affected by heavy metals pollutants discharged in aquatic environment because they are directly in contact with the medium separated only by the cell wall and the cytoplasmic membrane. Regarding content of protein and carbohydrates under the effect of the different concentrations of this element $\left(\mathrm{Co}^{+2}\right)$ the results provided that they affected the content of these metabolites with different degrees. Under lower concentrations of these elements the content of the measured metabolites increased but with different responses. The increase in content of these metabolic products with low concentrations of the tested heavy metals may be attributed to inhibition to export out these metabolites from the cells by heavy metals. On the other hand, inhibition in their accumulation induced by higher concentrations of heavy metals may be attributed to the toxic action of these heavy metals on the enzymatic reactions responsible for biosynthesis of these metabolites.
\end{abstract}

Keywords: Cyanobacteria, heavy metal, toxicity, total protein and total carbohydrate.

\section{Introduction}

Heavy metals can enter aquatic environment from point sources such as industrial premises and sewage treatment plants or from diffuse sources which include road and agricultural runoff and aerial deposition [1]. Alloway [2] illustrated that heavy metals or trace metals are the term applied to a large group of trace elements that are both industrially and biologically important. Micronutrients are another term used to call heavy metals because some of these elements are essential in small but critical concentrations, such as Co, Mo, Mn and Zn, although they are toxic at high concentrations. Algal communities in fact have been used in toxicity tests for environmental monitoring of heavy metal pollution [3]. Although dead algae have been utilized successfully in heavy metal adsorption experiments [4 and 5], living algae remove significantly more metal ions than nonliving algae at all metal concentrations examined, probably due to metabolic uptake and continuous growth [3 and 6]. Moreover, living algae possess intracellular polyphosphates which participate in metal sequestration, as well as algal extracellular polysaccharides that serve to chelate or bind metal ions [7, 8, 9 and 10].

Cobalt, a transition element, is an essential component of several enzymes and co-enzymes. It has been shown to affect growth and metabolism of plants. The unicellular green alga Monoraphidium minutum and the diatom Nitzschia perminuta were cultured under different concentrations of $\mathrm{Co}^{+2}$, growth and pigment content were slightly increased at low concentrations and inhibited by high $\mathrm{Co}^{+2}$ concentrations. The results concerning the effect of different concentrations of $\mathrm{Co}^{+2}$ on photosynthetic $\mathrm{O}^{2}$ evolution showed a reduction in the amount of $\mathrm{O}^{2}$ evolved by each alga in response to increasing $\mathrm{Co}^{+2}$ concentrations [11]

Lustigman et al [12] studied the effect of $\mathrm{Co}^{+2}$ on Chlamydomonas reinhardtii, they observed reduction of growth at $10 \mathrm{ppm} \mathrm{Co}{ }^{+2}$ and without change in the morphology of the cells or $\mathrm{pH}$. At $20 \mathrm{ppm} \mathrm{Co}^{+2}$, on the other hand, growth was considerably reduced compared to the control and the color of the organism became paler and the cells were clumped. In cyanobacteria, $\mathrm{CoCl}^{2}$ inhibits the formation of heterocyst, ammonia uptake, and nitrate reductase activity

The most prominent food algae are cyanobacteria (Spirulina). It can supply the human body with most of vitamins and essential inorganic and organic elements. It gets its own sun protective defense from the higher carotene production in intensive sun. Spirulina may contain from $65-70 \%$ protein. That means that all the eight essential amino acids are present in their correct ratios. It also contains chlorophyll of three times the amount of highly developed green plants. Chlorophyll is mentioned for the prevention and treatment of gastric duodenal ulcers, acne; to strengthen the heart muscles, build up immunity and energy, as a possible anti-bactericide and still unknown others [13]. This Spirulina can be used against certain illnesses for example, Acne, AIDS, Allergies, Anemia, Arthritis, Cancer, Depression, Protection against Radiation, Heavy metal detoxification, Cholesterol, Hypertension, Arteriosclerosis Pancreatitis, Loss of Vision, Cataracts and Glaucoma, Hepatitis and Cirrhosis, Gastric and Duodenal Ulcers, Sexual Vitality, Anti-ageing, Weight loss and a Slimming agent. However, the highest content of tyrosine may be the reason which suppresses hunger [13]. In our research we 
aimed to estimate the amount of proteins and carbohydrates in the blue-green alga spirulina under the effect of different concentrations of $\mathrm{Co}^{+2}$.

\section{Material and methods}

S. platensis was grown in Spirulina medium [14]. It consists mainly of the following: Macronutrients (Solution A) (NaCl: 1g, MgSO4. 7H2O: 0.2g, CaCl2. 2 H2O: 0.04g, FeSO4.7 H2O: 0.01g, Na-EDTA: 0.08g, K2HPO4: 0.5g, NaNO3: 2,5g,K2SO4:1.0g and NaHCO3:16.8g, in one liter distilled H2O). Stock solution B was prepared as following (NH4NO3: 0.023g, K2Cr2 (SO4)2. $27 \mathrm{H} 2 \mathrm{O}: 0.096 \mathrm{~g}$, NiSO4. 7H2O: 0.044g, Na2SO4. 7H2O: 0.018g, $\mathrm{Ti}$ (SO4)3: 0.040g and Co (NO3) 2. 6H2O: 0.044g in one litter of distilled water). Stock solution C was prepared as following (H3BO3: $2.820 \mathrm{~g}, \mathrm{MnCl} 2.4 \mathrm{H} 2 \mathrm{O}: 1.810 \mathrm{~g}, \mathrm{ZnSO} 4.7 \mathrm{H} 2 \mathrm{O}: 0.222 \mathrm{~g}$, CuSO4. 5H2O: $0.077 \mathrm{~g}$ andMoO3: $0.015 \mathrm{~g}$, in one liter distilled water). One $\mathrm{ml}$ from stock solution $\mathrm{B}+1.0 \mathrm{ml}$ from stock solution $\mathrm{C}$ were added to each $1000 \mathrm{ml}$ of solution $\mathrm{A}$.

The cultures were grown under controlled laboratory conditions. Culture experiments were conducted under a regime of 16 hour light/ 8 hour dark. The culture period lasted for 18 days. The cells of S. platensis were harvested by centrifugation at $5000 \mathrm{rpm}$ for $30 \mathrm{~min}$ using angle rotor centrifuge. The supernatants were discarded and the remaining pellets were used for the determination of carbohydrates, protein consequently, the following selected concentrations were 1.0, 1.5, 2.0, 2.5 and $3.0 \mathrm{mg} / \mathrm{l}$ respectively for $\mathrm{Co}^{+2}$.

Measurements of total proteins and its fractions:

In this investigation protein was determined by the method described by [15] which is the modification of the original Folin-phenol method of Lowry et al [16].

Preparation of algal extract for protein analysis:

Protein was extracted from the algal cells according to the method described by Rausch, [17].

\section{Determination of total proteins:}

Reagent A: $2.0 \mathrm{~g}$ potassium sodium tartrate and $100 \mathrm{~g}$ sodium carbonate dissolved in 1 liter of $0.5 \mathrm{~N} \mathrm{NaOH}(0.9$ $\mathrm{ml}$ used for each determination).

Reagent B: $2.0 \mathrm{~g}$ potassium sodium tartrate and $1.0 \mathrm{~g} \mathrm{CuSO} 4.5 \mathrm{H} 20$ dissolved in $100 \mathrm{ml} 0.1 \mathrm{~N} \mathrm{NaOH}(0.1 \mathrm{ml}$ was used for each determination).

Reagent C: one volume Folin ciocalteu reagent diluted ten-fold with distilled water $(3.0 \mathrm{ml}$ were used for each determination).

Reagent A was added first to one $\mathrm{ml}$ of clear extract and to the blank or standard solution (for the standard curve) in a test tube and heated in water bath at $50^{\circ} \mathrm{C}$ for $10 \mathrm{~min}$. cooled rapidly in ice. Reagent B was then added and the tube was left for at least $10 \mathrm{~min}$ at room temperature. Reagent $\mathrm{C}$ was then added and mixed well by whiter mixer, placed in water bath at $50^{\circ} \mathrm{C}$ for $10 \mathrm{~min}$., then cooled rapidly. The intensity of the blue color developed in each sample was measured using a spectrophotometer at $650 \mathrm{~nm}$ and readings were then related to the standard curve.

\section{Determination of water soluble proteins:}

Aliquots $(10 \mathrm{ml})$ of algal suspension were centrifuged. The algal precipitate was boiled in $10 \mathrm{ml}$ distilled water for two hours. After cooling, the water extract was centrifuged and the supernatant was decanted and completed to a definite volume by distilled water and analyzed for determination of soluble proteins following the same method for estimation of total protein content.

Determination of water-insoluble proteins:

It was calculated as the difference between the total and water-soluble protein fractions of the same sample.

\section{Measurements of carbohydrates content:}

Carbohydrates content was estimated according to the method described by Dubois et al, [18].

\section{Determination of total carbohydrates:}

In a test tube two $\mathrm{ml}$ of $\mathrm{N} \mathrm{HCl}$ were added to the-cell pellets -obtained from $5 \mathrm{ml}$ culture after centrifugation and shaken well for complete homogeneity. The mixture was transferred to a clean test tube and then boiled for $20 \mathrm{~min}$. After cooling at room temperature, the extract is clarified by centrifugation for five minutes at $2000 \mathrm{rpm}$. In a clean test tube $0.5 \mathrm{ml}$ of the clear supernatant and $0.5 \mathrm{ml}$ of $5 \%$ phenol solution was added and mixed well. To each tube $2.5 \mathrm{ml}$ of $98 \% \mathrm{H} 2 \mathrm{~S} 04$ were added rapidly so that the stream hit the liquid surface directly to produce good mixing. Tubes were equally agitated during the acid addition. Blank was also treated in the same manner, but $0.5 \mathrm{ml}$ distilled water was used instead of algal extract. After ten minutes, the 
tube were re-shaken and placed in a water bath at $25-30^{\circ} \mathrm{C}$ for $20 \mathrm{~min}$. The developed yellow-orange color was stable for several hours. The optical density was determined at $488 \mathrm{~nm}$ and compared to calibration standard curve.

\section{Determination of water- soluble carbohydrates:}

To estimate water-soluble carbohydrates, $5 \mathrm{ml}$ culture from each algal culture was centrifuged and the supernatant was decanted. After decantation, the algal precipitate was extracted by distilled water for two hours in a boiling water bath. After cooling, the soluble fraction was separated by centrifugation and completed to a definite volume. Then the water soluble carbohydrates were determined by the method mentioned previously in case of total carbohydrates.

Determination of water- insoluble carbohydrates:

It was calculated as the difference between the total carbohydrates and the water soluble carbohydrates of the same sample.

\section{Statistical analysis:}

All estimates of sample variability were given in terms of the SD. The data were means \pm SD of at least three independent experiments. The obtained data were analyzed statistically using the least significant difference (LSD) at 0.05 .

\section{Effect of different concentrations of $\mathrm{Co}^{+2}$ ion on protein content of $S$. platensis:}

Results obtained for protein content in S. platensis revealed that, although the values of total protein contents that obtained in control increased gradually till the end of the experiment (16 days), yet under the effect of tested element, It is clear from these data that protein content under the effect of $1.0,1.5$ and $2.0 \mathrm{mg} / \mathrm{l}$ increased gradually till the end of the experiment while at concentrations 2.5 and $3.0 \mathrm{mg} / \mathrm{l}$ Co the total protein content began to decrease after the 12th day of culturing (Table 1 and Fig1)

\section{Effect of different concentrations of $\mathrm{Co}^{+2}$ ions on carbohydrates content of S. platensis:}

On the light of the obtained experimental results for the effect of different concentrations of $\mathrm{Co}^{+2}$ ions on carbohydrates content of S. platensis after 4, 8, 12 and 16 day of culturing. The data recorded in Table (2) and graphed in Fig (2) showed that the content of total carbohydrates decreased gradually under the stress effect of $\mathrm{Co}^{+2}$. The degree of increase or decrease in the content of carbohydrates depends mainly on the length of culturing period.

\section{Figures and Tables}

Table 1: Protein content $(\mu \mathrm{g} / \mathrm{ml})$ of $S$. platensis after 4, 8, 12 and 16 days of culturing under the effect of different concentrations of $\mathrm{Co}^{+2}(\mathrm{mg} / \mathrm{l})$.

\begin{tabular}{|c|c|c|c|c|c|c|c|}
\hline \multirow{2}{*}{$\begin{array}{c}\text { Time } \\
\text { (days) }\end{array}$} & \multirow{2}{*}{ Parameters } & \multirow{2}{*}{ Control } & \multicolumn{5}{|c|}{ Different Concentrations of $\mathrm{Co}^{+2}(\mathrm{mg} / \mathrm{l})$. } \\
\hline & & & 1.0 & 1.5 & 2.0 & 2.5 & 3.0 \\
\hline \multirow{3}{*}{4} & Soluble & $14.22 \pm 0.05^{\mathrm{a}}$ & $15.12 \pm 0.02^{b}$ & $10.23 \pm 0.12^{\mathrm{a}}$ & $10.12 \pm 0.11^{\mathrm{d}}$ & $9.89 \pm 0.06^{\mathrm{f}}$ & $9.06 \pm 0.06^{\mathrm{f}}$ \\
\hline & Insoluble & $15.22 \pm 0.09^{\mathrm{a}}$ & $15.31 \pm 0.06^{\mathrm{a}}$ & $14.25 \pm 0.06^{b}$ & $13.91 \pm 0.07^{\mathrm{c}}$ & $12.05 \pm 0.07^{\mathrm{e}}$ & $11.99 \pm 0.05^{\mathrm{d}}$ \\
\hline & Total & 29.44 & 30.43 & 24.48 & 24.13 & 21.94 & 21.05 \\
\hline \multirow{3}{*}{8} & Soluble & $20.63 \pm 0.12^{\mathrm{a}}$ & $20.77 \pm 0.05^{\mathrm{a}}$ & $20.63 \pm 0.03^{\mathrm{a}}$ & $18.22 \pm 0.10^{\mathrm{b}}$ & $16.27 \pm 0.10^{\mathrm{c}}$ & $16.02 \pm 0.05^{\mathrm{d}}$ \\
\hline & Insoluble & $32.46 \pm 0.18^{\mathrm{a}}$ & $24.96 \pm 0.05^{b}$ & $28.66 \pm 0.01^{\mathrm{c}}$ & $15.73 \pm 0.08^{c}$ & $15.02 \pm 0.01^{\mathrm{d}}$ & $14.47 \pm 0.07^{\mathrm{d}}$ \\
\hline & Total & 53.09 & 45.73 & 49.29 & 33.95 & 31.29 & 30.49 \\
\hline \multirow{3}{*}{12} & Soluble & $24.34 \pm 0.03^{\mathrm{a}}$ & $24.83 \pm 0.07^{\mathrm{c}}$ & $23.12 \pm 0.06^{\mathrm{c}}$ & $23.05 \pm 0.04^{b}$ & $20.62 \pm 0.07^{c}$ & $18.20 \pm 0.09^{d}$ \\
\hline & Insoluble & $32.12 \pm 0.07^{\mathrm{a}}$ & $35.93 \pm 0.08^{\mathrm{e}}$ & $33.12 \pm 0.02^{b}$ & $29.12 \pm 0.02^{c}$ & $22.16 \pm 0.05^{\mathrm{d}}$ & $19.62 \pm 0.12^{\mathrm{e}}$ \\
\hline & Total & 56.46 & 60.76 & 56.24 & 52.17 & 42.78 & 37.82 \\
\hline \multirow{3}{*}{16} & Soluble & $26.41 \pm 0.03^{a}$ & $27.75 \pm 0.06^{\mathrm{a}}$ & $29.33 \pm 0.10^{c}$ & $25.00 \pm 0.05^{\mathrm{a}}$ & $24.38 \pm 0.08^{c}$ & $20.07 \pm 0.07^{\mathrm{d}}$ \\
\hline & Insoluble & $40.31 \pm 0.09^{\mathrm{a}}$ & $41.75 \pm 0.08^{a}$ & $43.18 \pm 0.10^{b}$ & $33.44 \pm 0.10^{c}$ & $23.26 \pm 0.03^{\mathrm{d}}$ & $21.85 \pm 0.05^{\mathrm{d}}$ \\
\hline & Total & 66.72 & 69.5 & 72.51 & 58.44 & 47.64 & 41.92 \\
\hline
\end{tabular}


Toxicity effect of Cobalt on total protein and carbohydrate of cyanobacteria Spirulina platensis

Table 2: Carbohydrates content $(\mu \mathrm{g} / \mathrm{ml})$ of $S$. platensis after 4, 8, 12 and 16 days of culturing under the effect of different concentrations of $\mathrm{Co}^{+2}(\mathrm{mg} / \mathrm{l})$.

\begin{tabular}{|c|c|c|c|c|c|c|c|}
\hline \multirow{2}{*}{$\begin{array}{c}\text { Time } \\
\text { (days) }\end{array}$} & \multirow{2}{*}{ Parameters } & \multirow{2}{*}{ Control } & \multicolumn{5}{|c|}{ Different Concentrations of $\mathrm{Co}^{+2}(\mathrm{mg} / \mathrm{l})$. } \\
\hline & & & 1.0 & 1.5 & 2.0 & 2.5 & 3.0 \\
\hline \multirow{3}{*}{4} & Soluble & $3.60 \pm 0.08^{\mathrm{a}}$ & $5.18 \pm 0.03^{\mathrm{d}}$ & $6.68 \pm 0.02^{c}$ & $6.75 \pm 0.03^{\mathrm{c}}$ & $4.79 \pm 0.07^{\mathrm{c}}$ & $4.32 \pm 0.03^{b}$ \\
\hline & Insoluble & $23.49 \pm 0.04^{\mathrm{a}}$ & $24.14 \pm 0.09^{b}$ & $28.69 \pm 0.07^{\mathrm{d}}$ & $20.43_{\mathrm{c}}^{ \pm} 0.12$ & $18.76 \pm 0.04^{\mathrm{c}}$ & $14.76 \pm 0.12^{\mathrm{d}}$ \\
\hline & Total & 27.09 & 29.32 & 35.37 & 27.18 & 23.55 & 19.18 \\
\hline \multirow{3}{*}{8} & Soluble & $5.29 \pm 0.05^{\mathrm{a}}$ & $6.55 \pm 0.10^{b}$ & $8.20 \pm 0.01^{b}$ & $8.89 \pm 0.15^{\mathrm{c}}$ & $8.03 \pm 0.03^{\mathrm{d}}$ & $7.92 \pm 0.15^{c}$ \\
\hline & Insoluble & $41.27 \pm 0.07^{\mathrm{a}}$ & $42.67 \pm 0.07^{b}$ & $37.69 \pm 0.07^{\mathrm{c}}$ & $35.37 \underset{c}{ \pm 0.11}$ & $32.62 \pm 0.10^{\mathrm{d}}$ & $29.34 \pm 0.11^{\mathrm{d}}$ \\
\hline & Total & 46.56 & 43.22 & 45.89 & 44.25 & 40.65 & 37.26 \\
\hline \multirow{3}{*}{12} & Soluble & $11.47 \pm 0.10^{\mathrm{a}}$ & $12.14 \pm 0.06^{\mathrm{a}}$ & $13.34 \pm 0.03^{b}$ & $13.39 \pm 0.10$ & $11.13 \pm 0.07^{\mathrm{a}}$ & $8.02 \pm 0.08^{c}$ \\
\hline & Insoluble & $47.13 \pm 0.07^{\mathrm{a}}$ & $48.77 \pm 0.03^{c}$ & $48.80 \pm 0.01^{\mathrm{a}}$ & $45.15 \pm 0.08$ & $33.19 \pm 0.02^{d}$ & $26.05 \pm 0.10^{\mathrm{e}}$ \\
\hline & Total & 58.6 & 60.91 & 62.14 & 58.54 & 44.32 & 34.07 \\
\hline \multirow{3}{*}{16} & Soluble & $12.14 \pm 0.08^{\mathrm{a}}$ & $12.30 \pm 0.04^{\mathrm{a}}$ & $12.01 \pm 0.02^{\mathrm{a}}$ & $10.06 \pm 0.07$ & $8.50 \pm 0.04^{c}$ & $6.68 \pm 0.07^{c}$ \\
\hline & Insoluble & $48.01 \pm 0.11^{\mathrm{a}}$ & $49.55 \pm 0.07^{b}$ & $42.30 \pm 0.15^{c}$ & $39.61 \pm 0.05$ & $27.44 \pm 0.12^{\mathrm{d}}$ & $19.01 \pm 0.03^{\mathrm{e}}$ \\
\hline & Total & 60.15 & 61.85 & 54.31 & 49.67 & 35.94 & 25.69 \\
\hline
\end{tabular}

Data are expressed in mean \pm SD $\quad$ Different superscripts are significant

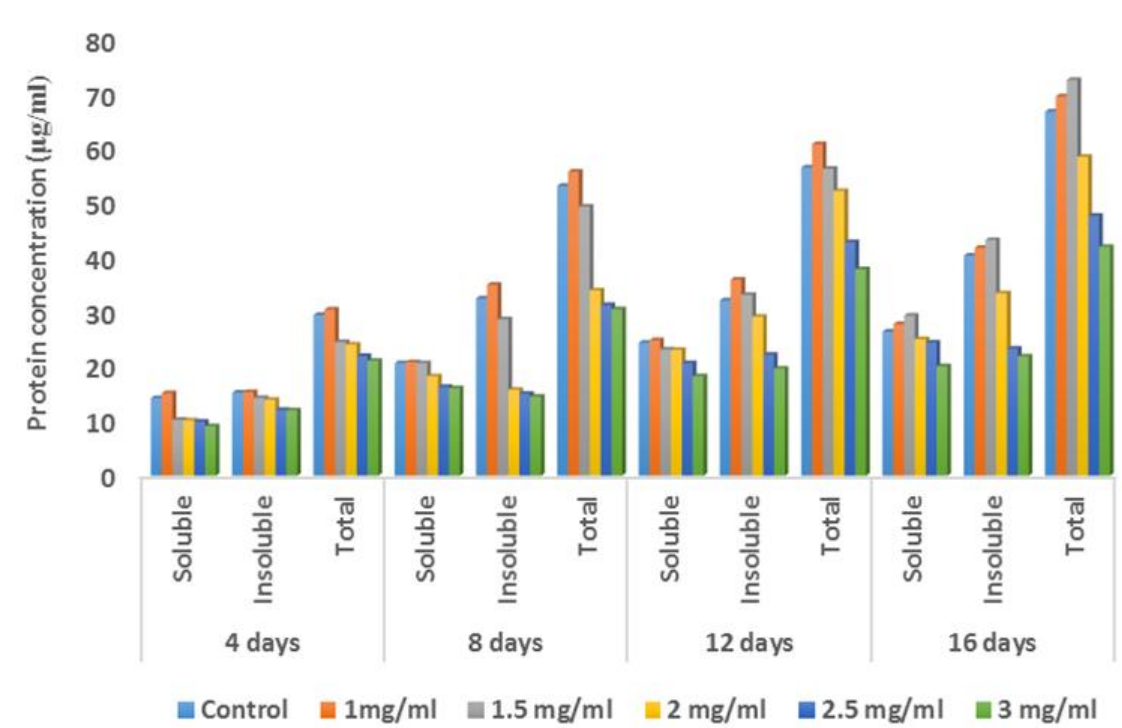

Figure 1: Effect of different $\mathrm{Co}^{+2}$ concentrations on proteins content $(\mu \mathrm{g} / \mathrm{ml})$ of $S$. platensis cultured for $4,8,12$ and 16 days of culturing 


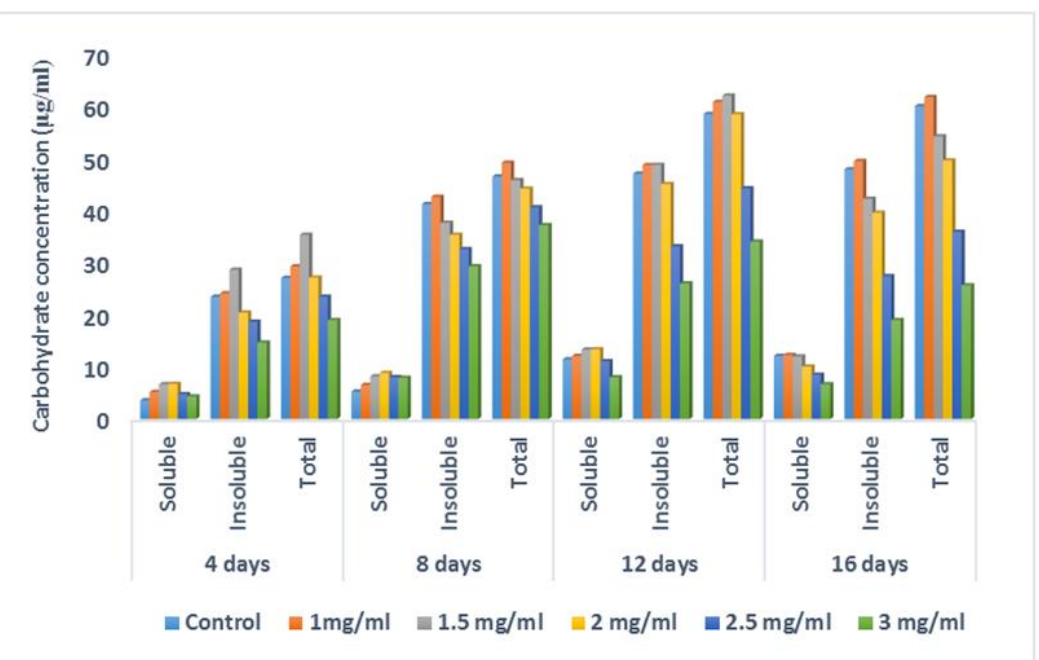

Figure 2: Effect of different $\mathrm{Co}^{+2}$ concentrations on carbohydrate content $(\mu \mathrm{g} / \mathrm{ml})$ of S. platensis cultured for 4 , 8,12 and 16 days of culturing.

\section{Discussion}

This work dealt with the effect of different concentrations of $\mathrm{Co}^{+2}$ ion on some important metabolites of the blue green alga S. platensis. Anent results obtained from protein content of S. platensis (soluble, insoluble and total) comparing to control, it is clear that protein content whether soluble, insoluble or total increased gradually with increasing the period of culturing till the $16^{\text {th }}$ day. That agrees with Thomas and Dumas, [19] who reported that protein content is usually higher in the early stages of growth and falls as the culture ages. However, several studies found that protein content of microalgae depends on the nitrogen source used in the culture medium [20, 21, 22, 23 and 24]. Another study reported that elemental and biochemical composition of Dunaliella primolecta were correlated positively with nitrogen concentration of the medium and this composition was influenced by the availability of the nitrogen which could be the reason for this phenomena [25].

Concerning the effect of $\mathrm{Co}^{+2}$ ions on the content of total protein, the obtained results indicated that low concentrations of $\mathrm{Co}^{+2}(1.0$ and $1.5 \mathrm{mg} / \mathrm{l})$ induced a significant increase in protein content of $S$. platensis till the $4^{\text {th }}$ day of culturing. Further increase in $\mathrm{Co}^{+2}$ levels was accompanied by a progressive reduction in protein content of the tested alga. These results are in agreement with those obtained by Stillwell and Holland [26], ElMazally [27] who reported that high concentrations of $\mathrm{Ni}^{+2}$ significantly decreased all proteins of Cricosphaera cartera. Additionally, Angadi and Mathad [28] found that total proteins content were inhibited at higher concentrations of $\mathrm{Co}^{+2}$ while lower concentrations showed stimulatory effect in Scenedesmus quadricauda. Also, [29] found that $100 \mu \mathrm{M} \mathrm{Co}^{+2}$ reduced the protein content of Haematococcus lacustris. Accordingly, accumulation of protein at low heavy metal concentrations may be one of the ways through which the algae can abolish their toxic effects, and/or may be due to increased respiration leading to the utilization of carbohydrates in increasing nitrogen metabolism. On the other hand, inhibition of protein accumulation induced by higher concentrations of heavy metals may be attributed to the toxic action of these heavy metals on the enzymatic reactions responsible for protein biosynthesis and the extent of such inhibition was concentration and $\mathrm{pH}$ dependent [30, 31, 32 and 33].

Regarding protein content under the effect of different concentrations of $\mathrm{Co}^{+2}$, the results cleared that under lower concentrations of $\mathrm{Co}^{+2}(1.0$ and $1.5 \mathrm{mg} / \mathrm{l})$ its content increased at the $4^{\text {th }}$ day of culturing. Further increase in the concentration of $\mathrm{Co}^{+2}$ the content of protein decreased gradually till the end of the experiment. These results coincides with those results obtained previously, that increase in protein content at low concentration of $\mathrm{Co}^{+2}$ and perhaps other heavy metals may be attributed to inhibition of protein export out of cells by heavy metals[29, 30,31, 34 and 35]. On the other hand, the decrease of protein under higher concentrations of heavy metal ions in case of $\mathrm{Co}^{+2}$ may be attributed to the toxic action of these heavy metals on the enzymatic reactions responsible for biosynthesis of proteins [36, 37, 38 and 39].

Regarding carbohydrates content in cultures amended by $\mathrm{Co}^{+2}$, the present results revealed that different concentrations of $\mathrm{Co}^{+2}$ induce gradually decrease in total carbohydrates content till the $16^{\text {th }}$ day of culturing. These findings are in agreement with those obtained by [40] who reported that concentrations of $\mathrm{Co}^{+2}$ accelerated carbohydrates content of Chlorella. Also [32] reported that the reduction pattern in the various carbohydrates in response to high concentrations of heavy metals could be accounted for inhibitory effect of heavy metals upon photosynthesis activity and/or utilization of carbohydrates as substrate in increasing nitrogen metabolism. 


\section{Conclusion}

The overall map of our results that content of protein and carbohydrates under the effect of the different concentrations of $\mathrm{Co}^{+2}$ the results proved that they affected the content of these metabolites with different degrees. Under lower concentrations of these elements the content of the measured metabolites increased but with different responses. These may be attributed to the toxic action of this heavy metal on the enzymatic reactions responsible for biosynthesis of these metabolites.

\section{References}

[1]. T. F. Zabel. Current standards and their relation to environmental behaviour and effects the case of lead. Science Total Environment. 78:1989, 187 -204

[2]. B. J. Alloway. Heavy metal in soil. Blakie Academic and professional. Pp. $42-52.1995$.

[3]. P. A. Terry and W. Stone. Biosorption of cadmium and copper contaminated water by Scenedesmus abundans. Chemosphere. 2002. 47: $249-255$.

[4]. A. Leusch, Z. R. Holan and B. Volesky. Biosorption of heavy metals $(\mathrm{Cd}, \mathrm{Cu}, \mathrm{Ni}, \mathrm{Pb}, \mathrm{Zn})$ by chemically-reinforced biomass of marine algae. Journal of Chemical Technology and Biotechnology. 62: 1995, $279-288$.

[5]. Z. Holan, B. Volesky and I. Prasetyo. Biosorption of cadmium by biomass of marine algae. Biotechnology and Bioengineering. 41 : $1998,819-825$

[6]. S. Maeda and T. Sakaguchi. Accumulation and detoxification of toxic metal elements by algae. Introduction to applied phycology. Akatsuka, $1^{\text {st }}$ edition. The Hage, the Netherlands. Pp14-137. 1990.

[7]. J. S. Turner and N. J. Robinson. Cyanobacterial Metallothioneins: Biochemistry and Molecular Genetics. Journal of Industrial Microbiology. 14:1995, 119-125.

[8]. C. Van Eykelenburg. A glucan from the cell wall of the Cyanobacterium. Antonie van Leeuwenhoek. 44:1978, 321 - 327.

[9]. D. D. Kaplan, D. Christi and S. M. Arad. Chelating Properties of Extracellular Polysaccharides from Chlorella sp. Applied Environment Microbiology.53: 1987, 2953 - 2956.

[10]. W. Zhang and V. Majidi. Monitoring the cellular response of Stichococcus bacillaris to exposure of several different metals using in vivo 31P NMR and other spectroscopic techniques. Environment Science Technology. 28: 1994, 1577 - 1581

[11]. M. M. El-Sheekh., A. H. El-Naggar., M. E. H. Osman and E. El-Mazaly. Effect of cobalt on growth, pigments and the photosynthetic electron transport in Monoraphidium minutum and Nitzchia perminuta. Brazil Journal of Plant Physiology. 15:2003, 159-166.

[12]. B. Lustigman., L. H. Lee and C. Weiss-Magasic. Effect of cobalt and $\mathrm{pH}$ on the growth of Chlamydomonas reinhardtii. Bulletin of Environmental Contamination and Toxicology. 55:1995, 65-72.

[13]. W. T. Harald. Spirulina, micro food, macro blessing. $4^{\text {th }}$ edition. Bermagui. NSW. Australia. Pp.18-29. 2004.

[14]. C. Zarrouk. Contribution a l'Etude d'une Cyanophycre sur la Croissance de la photosynthrse de Spirulina maxima. Stech Gardner (ed.), Geitler. These, Paris. 1966.

[15]. E. F. Hartee. A modification of Lowry method that gives a linear photometric response. Analytic Biochemistry. 1972. 48: 422-

[16]. O.M. Lowry., N. J. Rosebrough., L. A. Farr and R. J. Randall. Protein measurements with Folin phenol reagent Journal of Biological and Chemistry. 193: 1951, 265-275.

[17]. T. Rausch. The estimation of microalgal protein content and its meaning to the evolution of algal biomass. I., Comparison method for extracting protein. Hydrobiology. 78: 1981, 237 - 251.

[18]. M. Dubois., K. A. Gilles., J. K. Hamilton and F. Simth. Phenol-sulphoric acid colorimetric method for Carbohydrate determination. In: Method in Carbohydrate chemistry. Whist ler, L. R. 1951. 388-403. Academic Press New Youk.

[19]. P. Thomas and R. Dumas. Contribution a L'etude de Dunaliella salina culture bacterienes: nutrition composition. Tethys. 2: 1970, $19-28$.

[20]. L. V. Venkataraman and B. P. Nigan. Mass culturing of fresh water algae utilization as protein source. Phykos. 18: 1979, 83 - 95.

[21]. S. Boussiba and A. E. Richmond. C-Phycocyanin as a storage protein in the blue green algae Spirulina platensis. Archives of Microbiology. 125: 1980, 143 - 147.

[22]. D. M. El-Maghrabi. The biotechnology of culturing Dunaliella salina for the production of some valuable metabolites. M.Sc. Thesis. Faculty of Science. Alexandria. University. Egypt. 1970

[23]. H. M. Taha. Comparative physiological and chemo-taxonomical studies of some species of Dunaliella (Volvocales). Ph.D. Thesis. Faculty of Science. Alexandria. University. Egypt. 2002.

[24]. H. A. Said. Physiological and biochemical studies on the effect of crude oil and two of its derivatives on some microalgae. Ph.D. Thesis. Faculty of science, Fayoum University. Egypt. 2006.

[25]. I. Uriarte., A. Farias., J. S. Hawkins and B. L. Bayne. Cell characteristics and biochemical composition of Dunaliella primolecta Butcher conditioned at different concentrations of dissolved nitrogen. Journal of Applied Phycology. 5: 1993, 447 - 453.

[26]. E. F. Stillwell and J. R. Holland. Nickel effects on cell division, calcification, and cell protein in the coccolithophorid Cricosphaera carterae. Science of Biology Journal. 3: 1977. 401-408.

[27]. E. E. El-Mazally. Ecophysiological studies on the phytoplankton communities of River Nile at Kafr El-Zayat city with relevance to pollution with industrial effluents. Ph.D. Thesis. Botany. Department. Faculty of Science. Tanta University. Egypt. 2002.

[28]. S. B. Angadi and P. Mathad. Effect of chromium and nickel on Scenedesmus quadricauda (Turp.) de Berb. Phykos. 33:1994, 99 103 .

[29]. B. A. Hart and B. D. Scaife. Toxicity and bioaccumulation of cadmium in Chlorella pyrenoidosa. Environmental Research. 14: 1977, $401-413$.

[30]. I. A. Kobbia., W. Hofner., M. I. Naguib and Z. K. Ibrahim. Uses of laboratory cultures of some algae to predict heavy metal toxicity VI. Effect of various concentrations of $\mathrm{Cd}, \mathrm{Cr}, \mathrm{Ni}$ and $\mathrm{Zn}$ on the composition of amino acids and soluble proteins in Chlorella fusca. Bulletin Faculty of Science. Cairo University. 53: 1985, 249 - 263.

[31]. L. C. Rai., A. K. Singh and N. Mallick. Studies on photosynthesis, the associated electron transport system and some physiological variables of Chlorella vulgaris under heavy metal stress. Journal of Plant Physiology. 137:1991, 419 - 424.

[32]. A. H. El-Naggar. Growth and some metabolic activities of Chlorella and Scenedesmus in relation to heavy metal pollution in Gharbia Governorate. Ph.D. Thesis. Botany Department, Faculty of Science. Tanta University. Egypt. 1993.

[33]. M. Z. Nassar. Eco-physiological studies on phytoplankton along the western coast of Suez Gulf. Ph.D. Thesis. Faculty of Science. Botany Department. Tanta University. Egypt. 2000 
[34]. L. F. De-Filippis., R. Hampp and H. Ziegler. The effects of sub-lethal concentrations of zinc, cadmium and mercury on Euglena Growth and pigments. Journal of Plant Physiology. 101: 1981, 37 - 47.

[35]. L. F. De-Filippis., R. Hampp and H. Ziegler. The effects of sub-lethal concentrations of zinc, cadmium and mercury on Euglena II. Respiration, photosynthesis and photochemical activities. Archives of Microbiology. 128: 1981, 407 - 411.

[36]. M. E. H. Osman., A. H. El-Naggar., M. M. El-Sheekh and E. El-Mazally. Differential effects of Co2and Ni2on protein metabolism in Scenedesmus obliquus and Nitzschia perminuta. Environmental Toxicology and Pharmacology. 16: 2004, 169 - 178.

[37]. B. N. I. Tripathi and J. P. Gaur. Physiological behavior of Scenedesmus sp. during exposure to elevated levels of $\mathrm{Cu}$ and $\mathrm{Zn}$ and after withdrawal of metal stress. Protoplasma. 229: 2006, 1 - 9.

[38]. W. Barbara and W. Michael. Comparative studies of the heavy metal uptake of whole cells and different types of cell walls from Chlorella fusca. Biotechnology Techniques. 8: 1994, 227 - 232.

[39]. E. Afkar., H. Ababna and A.A. Fathi. Toxicological Response of the Green Alga Chlorella vulgaris, to Some Heavy Metals. American Journal of Environmental Sciences. 6: 2010, 230 - 237.

[40]. Z. K. Ibrahim. Heavy metal absorption and utilization by different kinds of algae. Ph.D. Thesis. Faculty of Science. Cairo University Egypt.1983. 